\title{
Recent Trends in Energy Harvesting Technology Using Composite Materials
}

\author{
Jae Hwan Jung, Dong-Min Lee, Young Jun Kim, and Sang-Woo Kim ${ }^{\dagger}$ \\ School of Advanced Materials Science \& Engineering, Sungkyunkwan University, \\ Suwon 16419, Korea

\section{복합소재를 이용한 에너지 하베스팅 기술 동향}

\author{
정재환, 이동민, 김영준, 김상우 ${ }^{\dagger}$ \\ 성균관대학교 신소재공학과
}

(Received June 3, 2019; Revised June 10, 2019; Accepted June 10, 2019)

\begin{abstract}
s
Triboelectric nanogenerators and piezoelectric nanogenerators are a spotlighted energy harvesting method that converts the wasted mechanical energy from the environment into usable electrical energy. In the case of triboelectric nanogenerators, researches have been mainly focused on high permittivity and flexible polymer materials, and in the case of piezoelectric nanogenerators, researches have been focused on ceramic materials exhibiting high polarization characteristics. Recently, many researches have been conducted to improve durability and power in various environments by using composite materials which have flexible properties of polymer, high permittivity, thermal resistance and high polarization properties of ceramics. This article reviews the energy harvesting studies reported about composites materials using ceramics and polymers.
\end{abstract}

Keywords: Energy harvesting, Composite, Ceramic, Triboelectric nanogenerator, Piezoelectric nanogenerator

\section{1. 서론}

사물인터넷을 실현하기 위한 다양한 지능 정보 기술이 발전함에 따라 데이터를 수집하기 위해서는 동시다발적 으로 구동되는 센서에 필요한 에너지 관련 기술의 수요가 높아지고 있다. 일반적으로 센서는 배터리를 전력원으로
구동되는데 배터리의 경우 에너지밀도가 꾸준히 향상되 고 있지만 부피와 무게가 상당하고 수명이 제한적이며, 유지비용이 필요하다는 명확한 단점을 가지고 있다. 또한 기존의 화석연료, 핵연료 등을 사용하여 만들어진 전기 에너지는 공해물질을 발생시키므로 환경적인 문제점도 가지고 있다. 이와 같이 인위적으로 만들어진 에너지의 


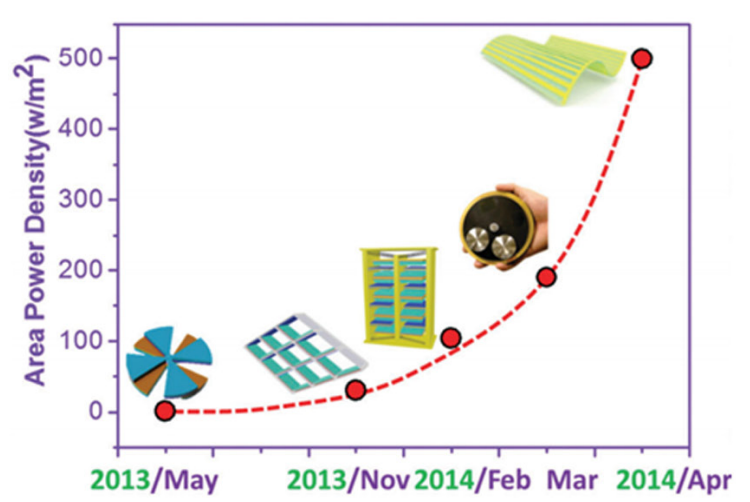

Fig. 1. 에너지 발전소자의 출력 및 센서 구동 전압 변화 추인)

사용은 인류가 지향하는 지속가능한 발전에 부합하지 않 는다. 따라서 자연에서 버려지는 여러 가지 에너지를 전 기 에너지로 전환하는 친환경 '에너지 전환' 기술에 대한 연구가 필요하다. ${ }^{1-3)} \mathrm{Fig} .1$ 에서 버려지는 기계적 에너지 를 전환하는 소자의 경우 출력이 지속적으로 증가하고 센 서의 경우 요구 전력이 지속적으로 감소하고 있기 때문에 에너지 전환 기술에 대한 연구가 꾸준히 진행된다면 미래 에는 센서의 전원을 친환경 에너지원으로 대체 가능할 것 으로 기대된다. ${ }^{4-5)}$

자연에서 버려지는 에너지는 크게 기계, 태양, 열에너 지로 분류될 수 있다(Fig. 2). 각각의 분류마다 태양에너 지를 이용하는 경우 태양전지, 열에너지를 이용하는 경우 열전소자와 초전소자 마지막으로 기계적 에너지를 이용 하는 경우 전자기 발전과, 압전소자 그리고 마찰전기 발

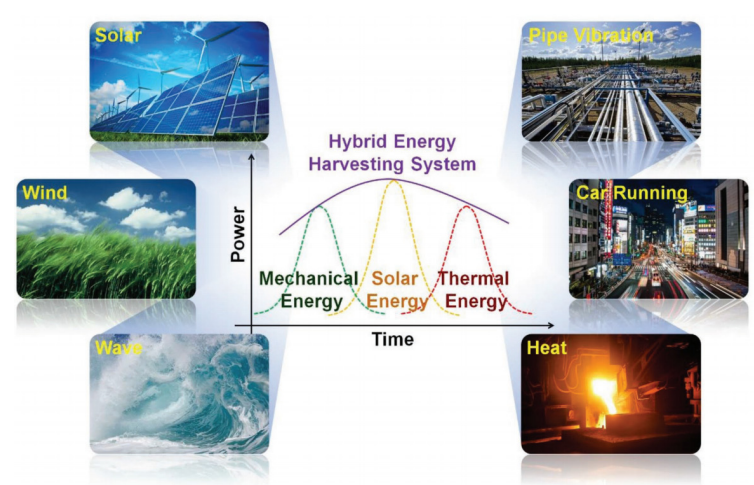

Fig. 2. 다양한 환경에서 버려지는 에너지를 활용한 지속가능한 에너 지 하베스팅 시스템 개략도1)

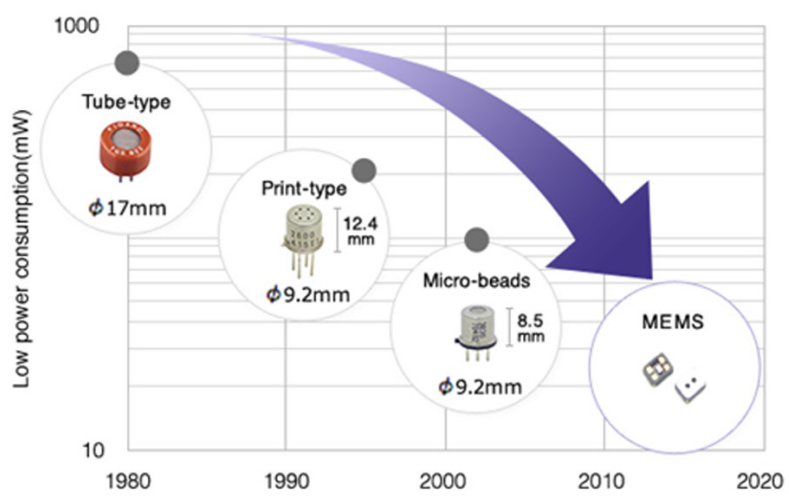

전 소자를 활용하여 에너지를 전환한다. 태양에너지와 열 에너지를 이용하는 에너지 전환 소자의 경우 태양광 에너 지와 온도의 차이로 인한 에너지를 어떻게 전환하는지가 주요 관심 분야이기 때문에 에너지원 자체는 비교적 단순 하며 에너지원을 크게 고려하지 않는다. 하지만 기계적 에너지의 경우 바람, 파도, 기계의 진동 그리고 인간의 움 직임 등 비교적 다양한 에너지원이 존재하고 각각의 에너 지원마다 환경, 진동수()ㅏㄴ 면적() 등 고려해야 할 변수도 다양하다. 고려해야 할 변수가 많은 만큼 적절한 재료의 선택과 주어진 환경에 맞는 구조설계를 통해 출력을 극대 화 할 수 있어 관련 연구가 활발하게 진행 중이다.

기계적 에너지를 전기에너지로 전환하는 대표적인 기 술로 압전 나노발전기(Piezoelectric Nanogenerator, $\mathrm{PENG}$ )와 마찰전기 나노발전기(Triboelectric Nanogenerator, TENG)가 있다. 압전 나노발전기의 경 우 국내는 물론 세계적으로 굉장히 많이 연구되는 분야 중 하나로서 2006년 이후 나노 구조체 관련 제조 기술이 발달함에 따라 에너지 하베스터로서 사용되는 연구가 활 발하게 증가하였다. 그 활용분야로서는 의료용 장치의 보 조 전원, 군수용 발전장치, 웨어러블 전자제품 등에 적용 될 것으로 기대하고 있으며 앞으로 인공심장, 심장 박동 기 등 인체 삽입형 소자나 건축 구조물 진단용 센서로서 활용하기 위한 연구도 활발히 진행되고 있다. 마찰전기 나노발전기는 Zhong Lin Wang 그룹에서 2012년에 최 초로 보고되었다. ${ }^{8)}$ 처음 보고된 이후 긴 시간이 흐르지 않았음에도 전 세계적으로 활발하게 연구되고 있으며, 국 
특 집 ㅁㅁ정재환, 이동민, 김영준, 김상우

내에서도 국가연구기관, 산업체, 대학교 등 많은 기관에 서 연구가 진행되고 있다. 연구 분야로서는 소자의 특성 상 가볍고 비용이 저렴하다는 장점이 있기 때문에 웨어러 블 소자로서 응용하기 위한 연구가 많이 진행되고 있으며 실제로 옷을 만들 때 사용되는 섬유와 편물 기술을 사용 하여 개발한 마찰전기 나노발전기 또한 보고된 바 있다. ${ }^{9}$ 그 외에도 기존의 교류형태의 출력을 내던 마찰전기 나노 발전기와 다르게 회전에너지를 구조와 회로를 최적화하 여 직류형태의 출력을 내는 소잠)의 개발 등 하베스터로 서 기초부터 응용까지 활발하게 연구되고 있다. 본 고에 서는 이처럼 기계적 에너지를 전환하는 발전소자 중 압전 나노발전기와 마찰전기 나노발전기에서 세라믹과 폴리 머 소재를 기반으로 한 복합소재 개발에 대해 서술하고자 한다.

\section{2. 마찰전기 니노발전기}

위의 서론에서 언급되었듯이, 마찰전기 나노발전기 (Triboelectric Nanogenerator, TENG)는 대표적으로 기계에너지를 이용하여 전기적 발전에 사용하는 소자들
중의 하나이다. 마찰전기 나노발전기는 마찰전기 대전현 상과 정전기적 유도현상을 구동원리로 하는데, 여기서 마찰전기 대전현상이란 서로 다른 물질들이 접촉되고 분 리될 때 일어나는 전기적 대전현상을 일컫는다. 표면 전 하밀도가 마찰전기 물질들을 이용하여 전기에너지를 생 성하는 핵심요소이다. ${ }^{6)}$ 마찰전기 물질들의 표면에 형성 되는 표면 마찰 전하의 분극은 마찰전기 표(Triboelectric Series)에 의해 결정되며, 표면에 대전된 전하들은 외부 회로의 포텐셜 차이를 만들어 전자의 흐름을 유도한 다. ${ }^{11)} \mathrm{Fig} .3$ 에서와 같이 서로 다른 두 물질이 접촉하면, 두 물질 사이의 계면에서 전하의 이동이 형성된다. 그리 고 두 물질 간의 마찰에 의해 표면에 반대 극성을 가진 전하가 생기면, 마찰전기 물질의 상대적인 움직임에 따 라 정전기적 평형을 유지하기 위해 전극사이에 전하가 흐르게 된다.

$$
\sigma=\epsilon_{0} \epsilon_{r} \frac{V}{d}
$$

위 (1)의 식에서 $\sigma$ 는 표면 전하밀도, $\varepsilon_{0}$ 는 진공 유전율, $\varepsilon_{\mathrm{r}}$ 는 상대 유전율, $d$ 는 두께, 그리고 $\mathrm{V}$ 는 전하 포텐셜 차
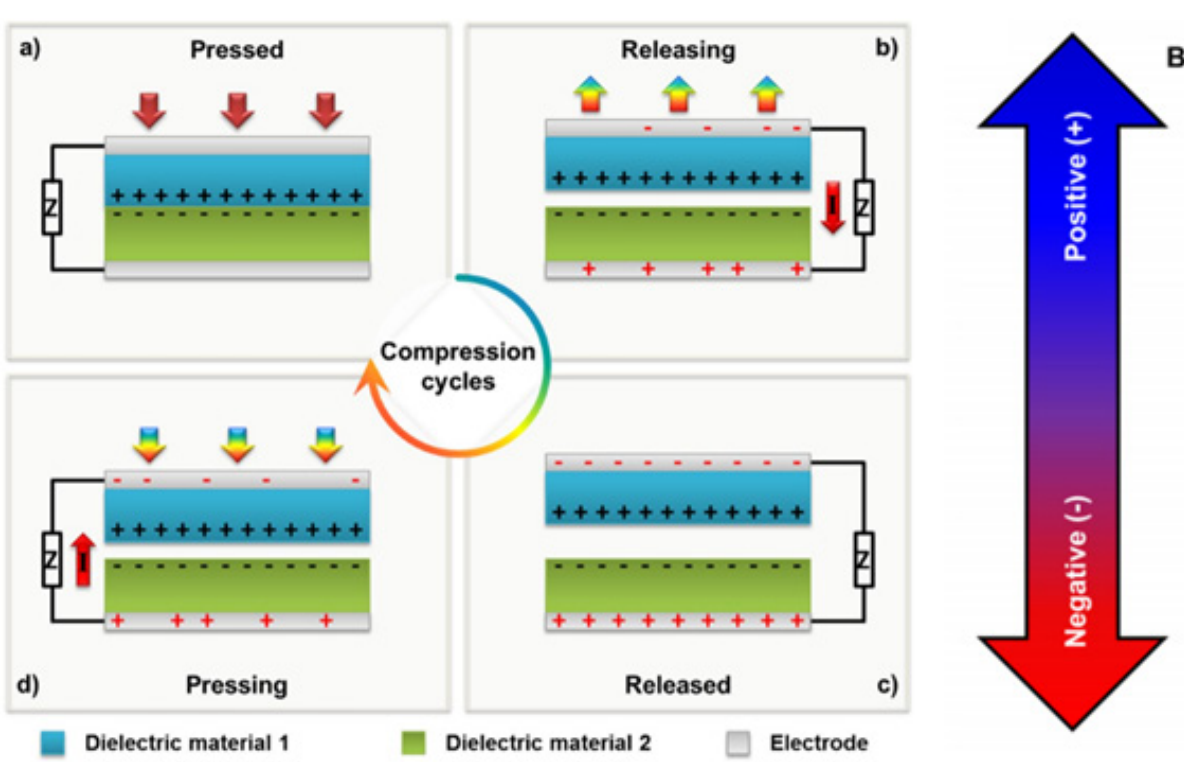

Polyurethane foam Box sealing tape (BOPP)

Rabbit's fur, Hair Glass

Mica

Wool

Nylon, dry skin Silk

Paper

Wood

Amber

Rubber Balloon

Nickel

Copper

Silver

Gold

Polystyrene

Acrylic

Polyvinyl chloride

Polyethylene

Polypropylene

Teflon(PTFE)

Fig. 3. 마찰전기 발전 소자의 일반적인 메커니즘 모식도 및 마찰 대전 시리즈2 3) 
를 의미한다. (1)식에서 확인할 수 있듯이, 표면 전하밀도 는 상대 유전율에 비례하고 두께에 반비례한다. 즉, 상대 유전율이 큰 물질일수록 유전층의 두께가 얇을수록 이동 하는 전하의 양이 커지며, 마찰전기 발전소자의 전기적 출력을 증가시킬 수 있다. 세라믹 재료는 금속, 고분자에 비해 높은 상대 유전율을 가지고 있어, 마찰전기 나노발 전기의 표면 전하밀도를 증가시키는 데에 장점이 있다. 그러나 세라믹 재료의 탄성 계수는 70 500 GPa 범위를 가져 금속보다 높은 값을 가지기 때문에 마찰전기 나노발 전기의 마찰물질로써 세라믹 재료만을 이용하기에 기계 적 안정성의 측면에서 큰 단점이 있다. ${ }^{12)}$ 따라서 세라믹 재료의 기계적인 성질의 약점을 보완하고 상대 유전율이 크다는 강점을 유지하기 위해 주로 탄성 계수가 낮고 유 연한 고분자 재료와 복합재료를 이루어 마찰전기 나노발 전기의 마찰물질로 이용하는 방안이 연구되어왔다. 대표 적인 복합소재로써 사용된 세 종류의 세라믹 재료들을 소 개해보려 한다.

\section{1 세라믹 나노 복합재료를 이용한 마찰전기 나노발전기}

2013년 Zhong Lin Wang 그룹에서는 $\mathrm{TiO}_{2}$ 나노재료 를 이용하여 catechin을 검출하는 자가발전 나노센서와

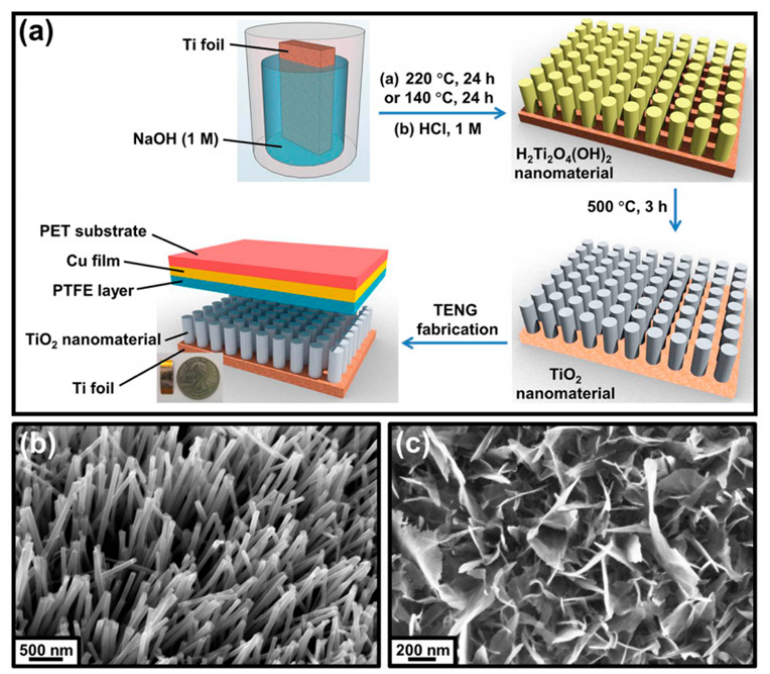

Fig. 4. (a) 마찰전기 발전소자의 제작과정. TNW 배열 (b)과 TNS 배 열 (c)로 덮힌 $\mathrm{Ti}$ 포일의 주사전자현미경 이미지 ${ }^{13)}$
화학적 변형을 통한 마찰전기 나노발전기의 전기적 출력 증가의 가능성에 대한 연구를 발표하였다. ${ }^{13)}$ Fig. $4 \mathrm{a}$ 에서 는 두 개의 평판을 지닌 층상구조를 도식적으로 나타내었 다. $\mathrm{TiO}_{2}$ 나노재료는 마찰전기 나노발전기의 마찰물질로 써 고안되었는데, $\mathrm{TiO}_{2}$ 나노재료, 즉, $\mathrm{TiO}_{2}$ nanowire (TNW)와 $\mathrm{TiO}_{2}$ nanosheet(TNS) 배열들은 $\mathrm{Ti}$ 포일 위에 서 두 단계의 합성 과정을 거쳐 형성되었다. 우선, $\mathrm{H}_{2} \mathrm{Ti}_{2} \mathrm{O}_{4}(\mathrm{OH})_{2}$ nanowire 배열과 $\mathrm{H}_{2} \mathrm{Ti}_{2} \mathrm{O}_{4}(\mathrm{OH})_{2}$ nanosheet 배열은 염기성 용액에서 이온교환 과정과 함 께 수열합성법(hydrothermal route)에 의해 Ti 포일 위 에 합성되었다. 더욱 높은 온도를 가해주면, $\mathrm{Ti}$ 포일과 $\mathrm{NaOH}$ 사이에서의 반응을 촉진하고, 더 밀집된 $\mathrm{Na}_{2} \mathrm{Ti}_{2} \mathrm{O}_{4}(\mathrm{OH})_{2}$ nanowire 배열이 형성된다. 그리고 TNW 배열과 TNS 배열이 미리 준비된 $\mathrm{H}_{2} \mathrm{Ti}_{2} \mathrm{O}_{4}(\mathrm{OH})_{2}$ nanowire 배열과 $\mathrm{H}_{2} \mathrm{Ti}_{2} \mathrm{O}_{4}(\mathrm{OH})_{2}$ nanosheet 배열의 열 처리를 통해 얻을 수 있다. TNW와 TNS의 평균 지름은 주사전자현미경(SEM) 이미지를 통해 각각 $67.2 \mathrm{~nm}$ 와 $9.4 \mathrm{~nm}$ 로 확인되었다(Fig. $4 \mathrm{~b}, \mathrm{c}$ ). 또 다른 평판에서는, polyethylene terephthalate(PET)가 유연성, 경량, 저 비용 등의 장점에 의해 기판으로 선택되었다. 구리 박막 이 전극으로써 $\mathrm{PET}$ 기판과 polytetrafluoroethylene (PTFE) 층 사이에 적층되었다. 여기서 사용된 PTFE는 가공이 쉽고 평평한 표면을 갖는다는 장점과 더불어, $\mathrm{TiO}_{2}$ 에 비해 상대적으로 전자를 끌어당기고 보유하는 능 력이 크기 때문에 마찰전기 나노발전기의 전기적인 출력 을 높이는 데에 기여한다. Fig. 5a, b에서 확인할 수 있 듯이 $\mathrm{TiO}_{2}$ 의 표면에 흡착된 catechin의 농도가 증가함에 따라 마찰전기 나노발전기의 개회로 전압이 증가한다. 이 러한 전기적인 출력이 증가하는 주요한 원인은 catechin
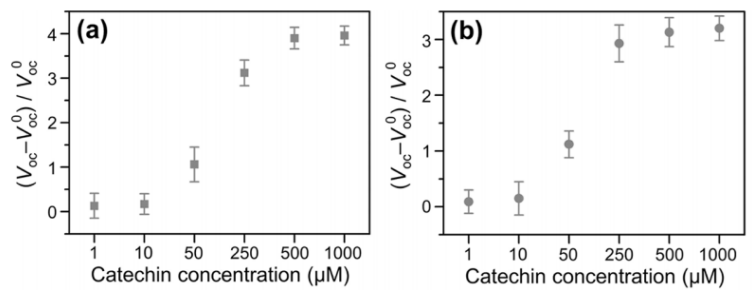

Fig. 5. (a) TNW 배열과 (b) TNS 배열 기반의 마찰전기 발전소자의 생성된 개회로 전압 비율 $\left(\left(\mathrm{V}_{\mathrm{OC}}-\mathrm{V}_{\mathrm{OC}}\right) / \mathrm{N}_{\mathrm{OCC}}\right)^{13)}$ 
(a)

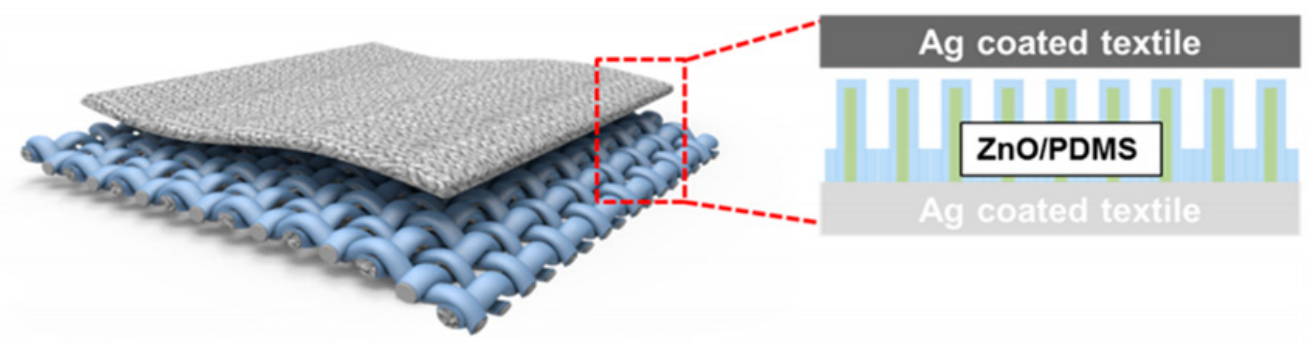

(b)
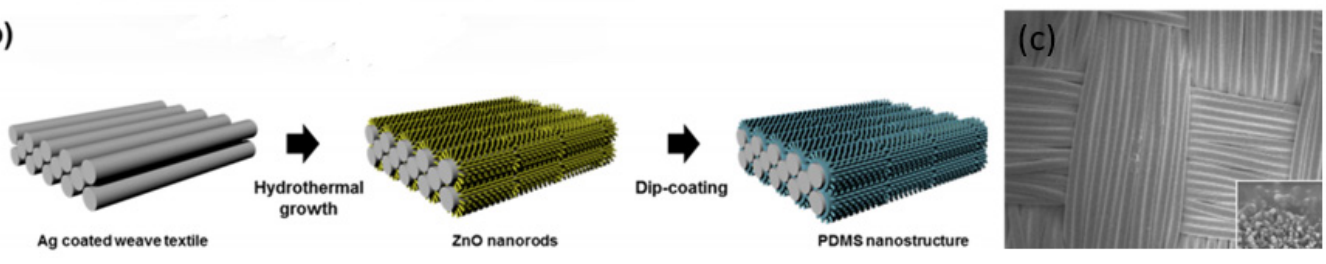

Fig. 6. 웨어러블 마찰전기 발전소자의 도식적인 설명 (a)과 PDMS 나노패턴구조의 제작과정 (b). 나노패턴된 PDMS가 있는 섬유의 전계방출 형 주사전자현미경 이미지. 내부 이미지는 ZnO NR 형판의 PDMS 나노패턴을 선명하게 보여주는 고배율 이미지 (c) $)^{14)}$

의 인다이올기와 $\mathrm{TiO}_{2}$ 나노재료의 표면에 존재하는 $\mathrm{Ti}$ 원 자 간의 리간드-금속 전하이동작용에 의한 $\mathrm{TiO}_{2} /$ catechin 복합소재의 새로운 성질에 있다고 설명하였다.

2015년 ZnO nanorod 배열에 기반을 둔 은(Ag)이 코 팅된 섬유와 polydimethylsiloxane (PDMS) 나노패턴 을 마찰물질로써 사용하여 높은 전기적인 출력을 얻은 연 구가 발표되었다. ${ }^{14)}$ 이 연구에서는 $\mathrm{ZnO}$ nanorod 배열을 틀로써 이용한 $\mathrm{PDMS}$ 나노패턴이 은(Ag)이 코팅된 섬유 기판위에 합성되었다. 합성과정은 $\mathrm{ZnO}$ 의 수열합성법 (hydrothermal growth method)와 PDMS 용액의 딥 코팅(dip-coating)방식으로 이루어진다(Fig. 6a, b.). 이러한 나노패턴을 사용하면, 섬유와 $\mathrm{PDMS}$ 의 접촉과 분 리 동안 실질적인 접촉면적과 마찰을 증가시킴으로서 마 찰전기 효과를 촉진시킬 수 있다. Fig. $6 \mathrm{c}$ 는 평면으로 짜 이고 은(Ag)이 코팅된 섬유에 나노패터닝된 PDMS을 관 찰한 전계방출형 주사전자현미경(field-emission scanning electron microscopy, FE-SEM)의 이미지이 다. 이 이미지를 통해 $\mathrm{ZnO}$ nanorod 형판(template)이 지지된 섬유 기판위에 PDMS 나노패턴이 성공적으로 미 세한 수준으로까지 형성된 것을 확인할 수 있다. 위와 같 이 제작된 마찰전기 발전소자가 높은 전기적인 출력을 보 이는지 검증하기 위하여, 나노패턴되지 않은 PDMS로 제 작된 마찰전기 발전소자와 전기적 출력을 비교하였다. 두
종류의 마찰전기 발전소자 모두 $10 \mathrm{kgf}$ 에 해당하는 힘을 수직한 방향으로 가해주었다. 나노패턴되지 않은 PDMS 에서는 약 $30 \mathrm{~V}$ 의 출력 전압과 $20 \mu \mathrm{A}$ 의 출력 전류가 관 찰되었다. 반면에 나노패턴이 된 마찰전기 발전소자의 경 우, 출력 전압과 전류 각각 $120 \mathrm{~V}$ 와 $65 \mu \mathrm{A}$ 로 나노패턴되 지 않은 마찰전기 발전소자보다 훨씬 높은 출력을 갖는 것을 관찰할 수 있다(Fig. $7 \mathrm{a}-\mathrm{d}$.).

2017년에 본 그룹에서 높은 유전율에 의해 우수한 전 하보유 능력을 지닌 $\mathrm{BaTiO}_{3}(\mathrm{BTO})$ 와 전기적으로 조절 가
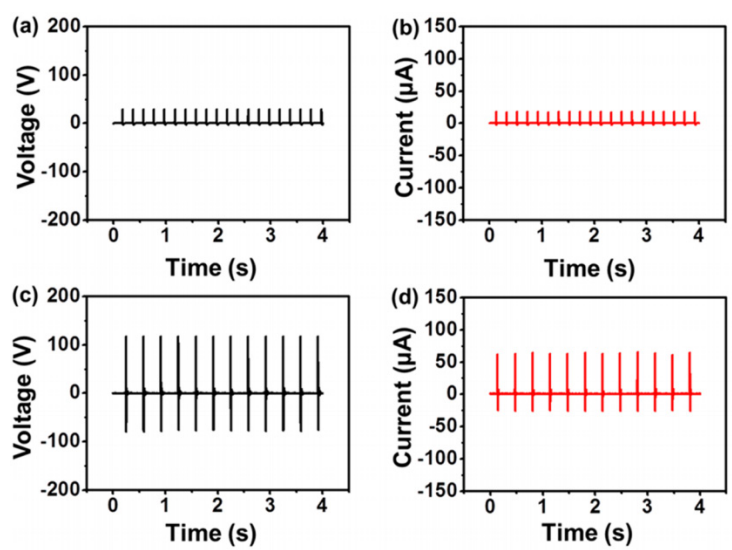

Fig. 7. 웨어러블 마찰전기 발전소자의 전력성능. (a), (b) 나노패턴이 없는 PDMS에 기반을 둔 웨어러블 마찰전기 발전소자의 출 력 전압과 전류. (c), (d) 나노패턴된 PDMS에 기반을 둔 웨어 러블 마찰전기 발전소자의 출력 전압과 전류.14) 
(a)

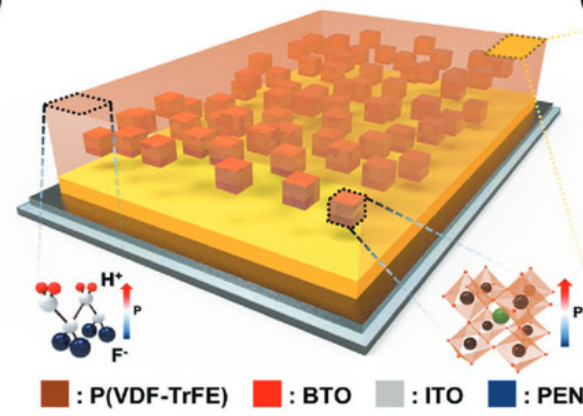

(c)

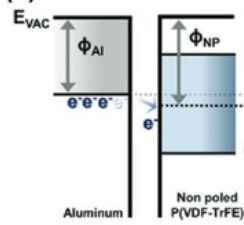

(d)

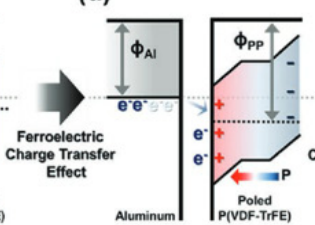

(b)

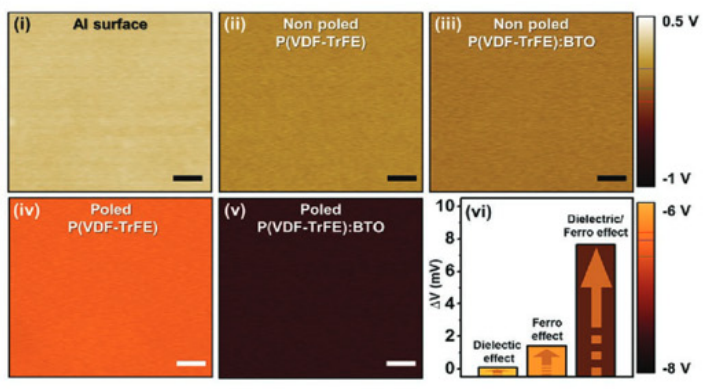

(e)

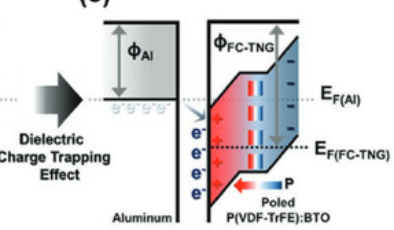

Fig. 8. (a) 강유전체 복합재료에 기반을 둔 마찰전기 발전소자의 도식적인 설명. (b) P(VDF-TrFE)의 강유전체 성질과 유전체인 BTO에 의해 유도된 다른 표면 전하 포텐셜을 보이는 KPFM 연구. (c) 구동원리 1, 알루미늄 (Al)과 분극되지 않은 P(VDF-TrFE)사이의 상대적으로 적은 전하의 이동, (d) 구동원리 2, 분극된 P(VDF-TrFE)의 강유전체 효과에 의한 밴드 변화, (e) 구동원리 3, 큰 전하이동을 야기하는 유전체 BTO에 의한 급격한 밴드변화, (f) $1130 \mathrm{~V}$ 의 출력 전압과 $1.5 \mathrm{~mA}$ 의 출력 전류를 갖는 높은 전력 성능 15$)$

능한 분극에 의해 강한 마찰전기적 전하이동 성질을 갖는 Poly(vinylidenefluoride-co-trifluoroethylene) $(\mathrm{P}(\mathrm{VDF}-\mathrm{TrFE}))$ 로 구성된 나노복합재료를 통해 높은 출 력을 보이는 마찰전기 나노발전기에 대한 연구을 발표하 였다. ${ }^{15)} \mathrm{Fig} .8 \mathrm{a}$. 에서 강유전체인 $\mathrm{P}(\mathrm{VDF}-\mathrm{TrFE})$ 공중합 체 속에 $\mathrm{BTO}$ 나노입자들이 잘 박혀있는 구조를 도식화 하였다. $\mathrm{P}(\mathrm{VDF}-\mathrm{TrFE})$ 공중합체는 고분자 재료로써 탄 성계수가 상대적으로 낮은 장점을 이용할 수 있을 뿐만 아니라, 강유전체 물질로써 분극을 시킴에 따라 마찰전기 대전효과를 향상시켜 전기적 출력을 높일 수 있다. ${ }^{16)}$ $\mathrm{BTO}$ 나노입자들은 이러한 마찰전기 나노발전기 구조 속 에서 강하게 전하를 붙잡는 역할을 하는데, $\mathrm{BTO}$ 의 높은 유전체적 성질이 $\mathrm{P}(\mathrm{VDF}-\mathrm{TrFE}): \mathrm{BTO}$ 나노복합체의 정 전용량을 획기적으로 증가시키기 때문이다. 이를 실험적 으로 검증하기 위해 Kelvin Probe Force Microscopy $(\mathrm{KPFM})$ 을 이용하여 표면 전하 포텐셜을 측정하였다. $\mathrm{BTO}$ 를 첨가한 $\mathrm{P}(\mathrm{VDF}-\mathrm{TrFE}): \mathrm{BTO}$ 나노복합재료가 $\mathrm{BTO}$ 가 첨가되지 않은 순수한 $\mathrm{P}(\mathrm{VDF}-\mathrm{TrFE})$ 보다 전하 포텐셜 차 (charge potential difference, $\mathrm{CPD}$ )가 증가 하였음을 확인하였다(Fig. 8b.). 다른 일함수를 갖는 두
마찰물질 사이의 표면 전하 포텐셜의 차이가 더 클수록, 더 많은 전하의 이동이 일어나기 때문에 결국 전기적 출 력이 더욱 커지게 된다(Fig. $8 \mathrm{c}-\mathrm{e}$.). 가장 큰 전하 포텐 셜 차이를 갖는 알루미늄 $(\mathrm{Al})$ 과 분극된 $\mathrm{P}(\mathrm{VDF}-$ $\mathrm{TrFE}): \mathrm{BTO}$ 사이의 출력 전압과 전류는 각각 $1130 \mathrm{~V}$ 와 $1.5 \mathrm{~mA}$ 에 도달하였다(Fig. 8f.).

\section{3. 압전 나노발전기}

32 개의 결정학적 점군을 가진 결정질 물질중 432 대칭 점군을 제외한 20 개의 비중심대칭을 가지는 물질들이 압 전 특성을 가지고 있다. 이 물질들은 외부에 기계적 에너 지에 의해 변형이 일어나게 되면 물질 표면에 전위가 생 기게 된다 ${ }^{17,18)}$ (Fig. 9.). 이를 압전효과(piezoelectric effect)라 부르고 이 효과를 이용하여 주변에 버려지는 기 계적 에너지를 전기에너지로 바뀌주는 압전 나노발전기 에 대한 연구들이 꾸준히 보고되어 왔다. 특히 세라믹 소 재는 높은 내열성을 가지고 있지만 기계적으로 강한 취성 을 가지고 있어 세라믹 소재만을 이용하여 기계적 에너지 를 하베스팅 하는 것에 한계가 있다. 이를 보안하기 위해 


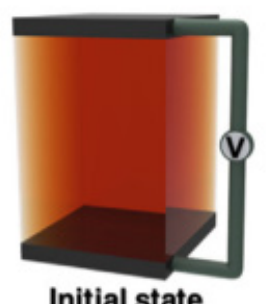

Initial state
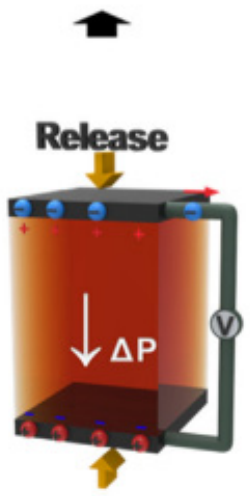
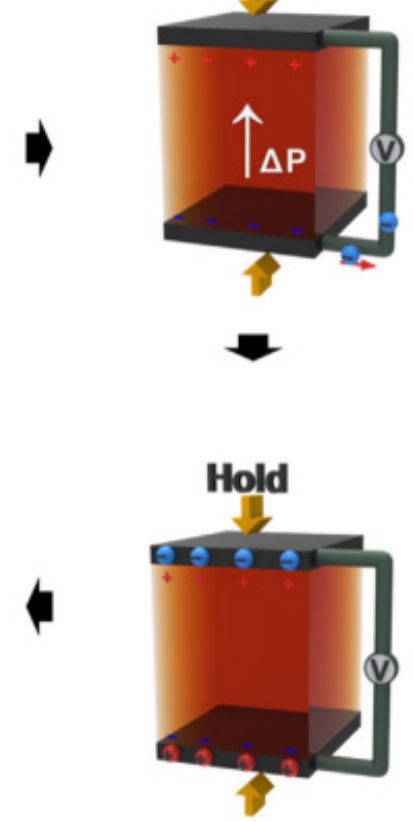

Fig. 9. 압전효과를 이용한 에너지 하베스팅 소자의 구동 원리 ${ }^{18)}$

세라믹 물질만을 압전 소재로 이용하지 않고 다양한 복합 재료를 이용하여 기계적 한계를 극복하고자 하는 연구들 이 꾸준히 진행되어 오고 있다. 페로브스카이트 강유전체 산화물은 높은 유전율과 자발분극 특성을 가지고 있는 것 으로 알려져있어 높은 압전 효율을 보이며 대표적으로 $\mathrm{BaTiO}_{3}(\mathrm{BTO}), \mathrm{Pb}(\mathrm{Zr}, \mathrm{Ti}) \mathrm{O}_{3}(\mathrm{PZT}), \mathrm{ZnSnO}_{3}$ 와 같은 물 질들이 있다. 이러한 페로브스카이트 강유전체 산화물 박 막이나 세라믹 나노 입자, 나노 와이어와 압전 특성을 가 진 폴리머의 복합재료를 이용하여 외부의 기계적 변위에 대해 유연하게 반응할 수 있게 하는 연구에 대해 소개하 고자 한다.

\section{1 세라믹 나노 복합재료를 이용한 압전 나노발전기}

국내 한국과학기술원 이건재 교수 연구팀은 2012년에 $\mathrm{BTO}$ 나노 입자, 탄소나노튜브, 그래핀옥사이드와 polydimethylsiloxane(PDMS) 폴리머를 이용한 압전 발전소자를 발표하였다. ${ }^{19)}$ 이 연구에서는 세라믹 입자와 폴리머의 액체상태에서 스핀 코팅과 바 코팅 방법을 이용 하여 유연한 대면적 압전 필름을 제작에 성공 하였다. 또 (a) NPs CNT or RGO

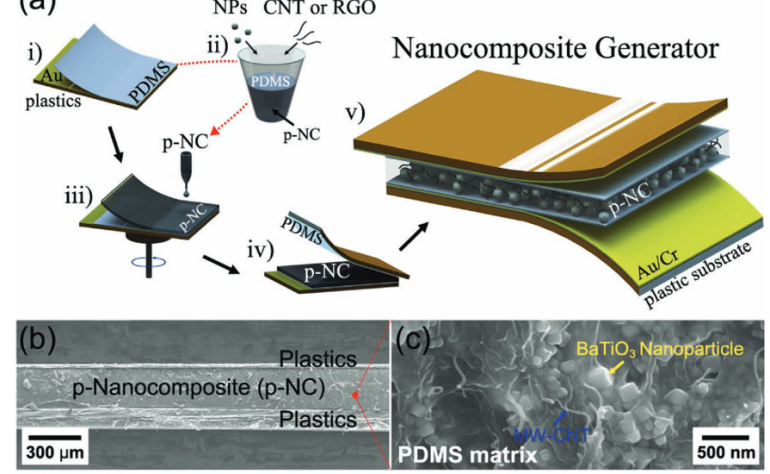

Fig. 10. (a) PSMS, BTO 나노입자, CNT, RGO 복합재료(p-NC)의 합성과정 모식도. (b) p-NC의 단면 전자 현미경 사진. (c) BTO 나노입자가 PDMS에 embedded 되어 있는 전자 현 미경 사진(19)

한 내구성 실험에서도 일주일 이상 압전 출력의 감소가 보이지 않는 안정적인 출력을 확인하였다. Fig. $10 \mathrm{a}$ 를 보 면 압전 나노발전기 소자의 제작 과정을 확인 할 수 있는 데, 제작 과정에서 고려해야 할 사향은 $\mathrm{PDMS}$ 내부에 $\mathrm{BTO}$ 나노 입자만을 첨가한 것이 아닌 탄소 나노 튜브 (CNT)와 함께 첨가했다는 점이다. $\mathrm{BTO}$ 는 그 자체만으로 압전 특성을 가지는 물질이기 때문에 PDMS 내부에 $\mathrm{BTO}$ 나노 입자를 첨가함으로서 유연한 압전 소자를 만들 수 있다. 하지만 단순히 BTO만을 첨가 할 경우에는 PDMS 내부에 $\mathrm{BTO}$ 가 고르게 분포하지 못하여 외부의 응력을 고 르게 전달받지 못해 나노 입자들은 낮은 압전 포텐셜을 보이게 된다. 하지만 $\mathrm{CNT}$ 와 함께 $\mathrm{BTO}$ 나노 입자를 첨가 할 경우 $\mathrm{CNT}$ 가 $\mathrm{PDMS}$ 내부에서 $\mathrm{BTO}$ 가 고르게 퍼질 수 있도록 도와주고 고르게 퍼진 나노 입자는 CNT가 없는 압전 소자에 비해 높은 압전 포텐셜을 가지게 된다(Fig. 10b, c.).

고려대학교 조진한 교수 연구팀과 본 그룹에서는 BTO 의 $20 \mathrm{~nm}$ 이하의 올레인산 리간드를 가진 나노 입자 $\left(\mathrm{OA}-\mathrm{BTO}_{\mathrm{NP}}\right)$ 와 카르복시산 $(\mathrm{COOH})-$ 작용기를 가진 유 기물 매개체 $(\mathrm{PAA})$ 를 이용하여 적층 구조의 세라믹 유기 물 복합소재를 발표하였다 ${ }^{20)}$ (Fig. 11a.). 작용기를 가진 유기물 매개체들의 화학적 결합을 이용한 적층 방법은 압 전 물질의 층수를 정확하게 조절할 수 있고 용매를 이용 한 적층방식에서 나타나는 정전기적 반발력을 제거하여 
(a)

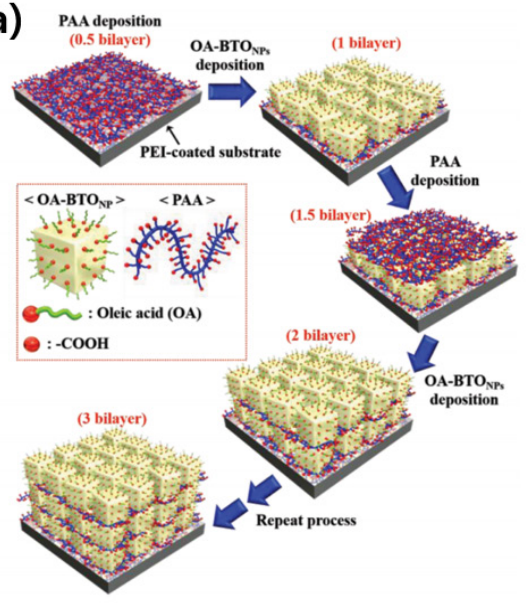

(b)
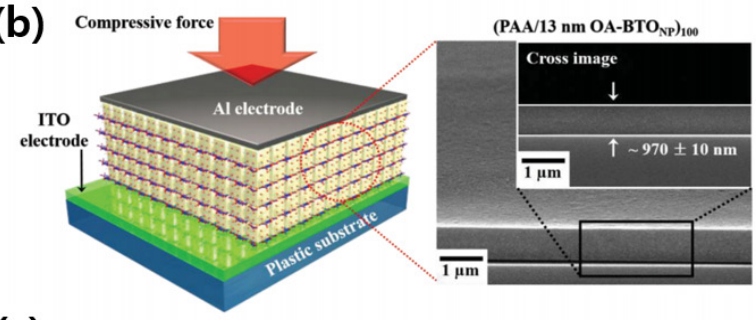

(c)

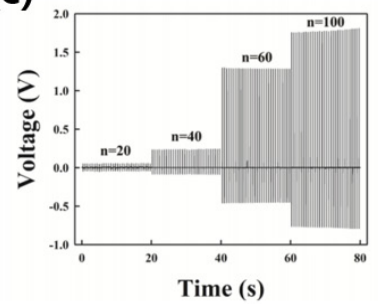

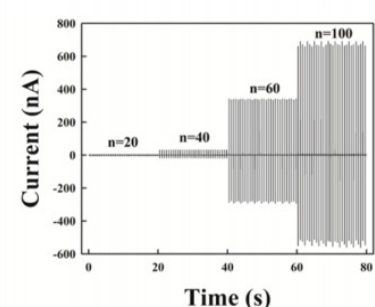

Fig. 11. (a) OA-BTONP와 PAA를 이용한 적층법 모식도. (b) 복합재료를 이용한 압전발전 소자를 도식화한 그림과 전자현미경 사진. (c) OA$\mathrm{BTONP}$ 와 PAA의 적층수에 따른 출력 그래프20)

고품질 박막 형성하여 누수 전류를 억제할 수 있었다. 또 한 기존 압전 물질과 다르게 적층된 물질의 수가 많아질 수록 높은 압전 특성을 보이는 세라믹 유기물 적층 구조 의 복합소재 개발에 성공하여 세라믹 나노 입자의 새로운 구조를 제시하였다(Fig. 11b, c.). Science and Technology Beijing 대학의 Yue Zhang 교수 연구팀은 생체 친화적이고 저렴한 물질인 박테리아 셀룰로오스 박
막과 BTO 나노 입자를 물속에 동시에 넣어 박테리아 셀 룰로오스가 나노 입자들을 흡수하고 이를 건조하는 간단 한 방식으로 $\mathrm{BTO} /$ 박테리아 셀룰로오스 종이 합성을 성 공하였다21) (Fig. 12a-g.). 이는 기존 BTO/PDMS 복합 구조 보다 10 배 높은 출력을 보여주었고 $1.5 \mathrm{~V}$ 의 안정적 인 출력으로 $\mathrm{LCD}$ 스크린의 구동하는데 성공하였다. 상 용화된 박테리아 셀룰로오스 종이를 이용하여 비교적 간
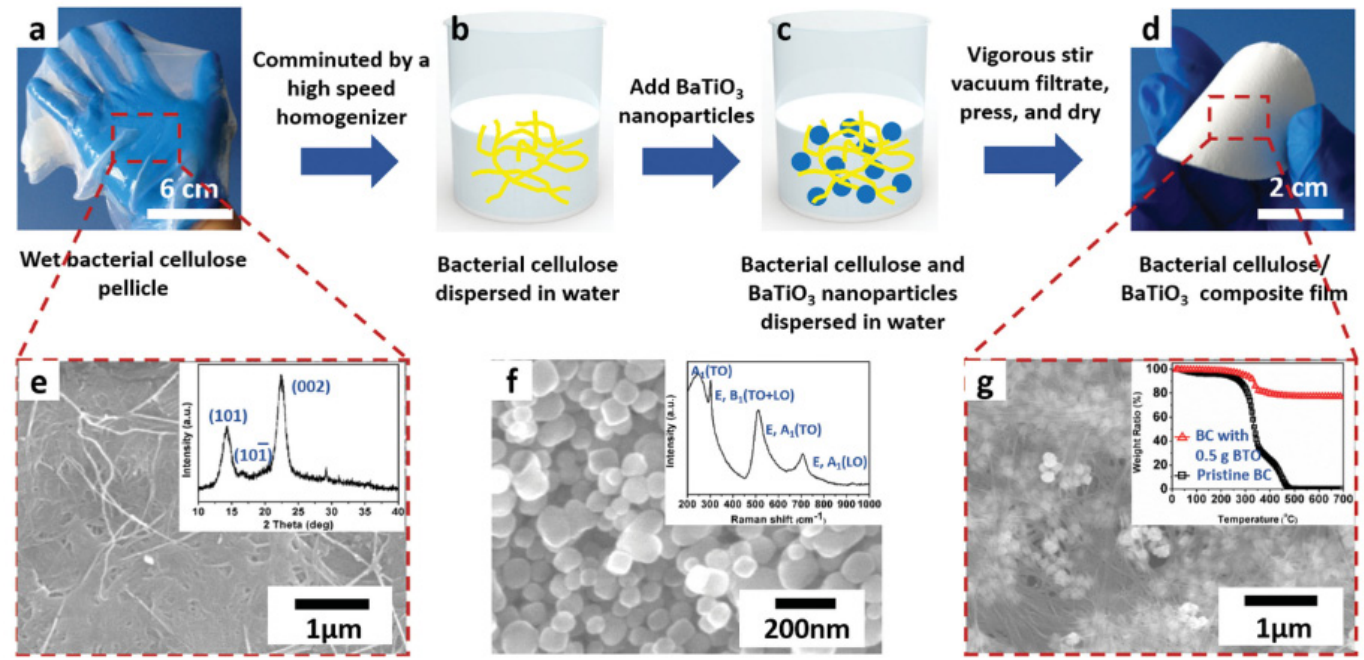

Fig. 12. (a)-(d) BTO 나노입자와 박테리아 셀룰로오스를 복합소재 합성법 모식도. (e) 박테리아 셀룰로오스의 전자현미경 사진 및 X선 회 절 패턴 분석. (f) BTO 나노입자의 전자현미경 사진 및 라만 분광 데이터 $(\mathrm{g})$ 압전 복합소재의 전자현미경 사진과 열 분해도 측정21) 


\section{특 집}

(a)

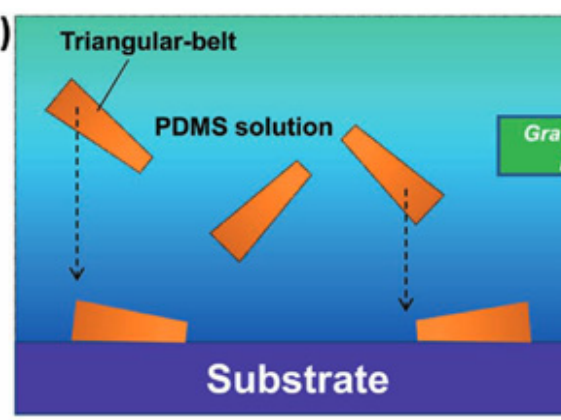

(b)

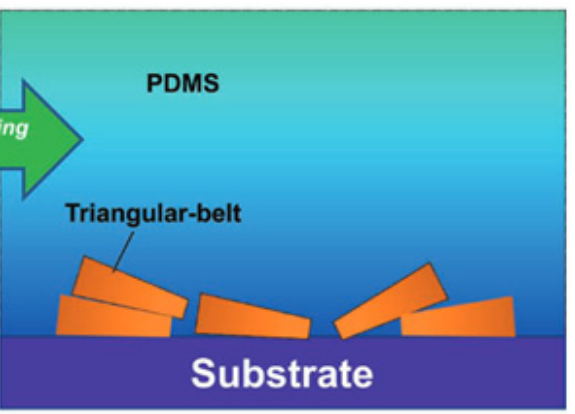

(c)

\section{$\mathbf{F}$}

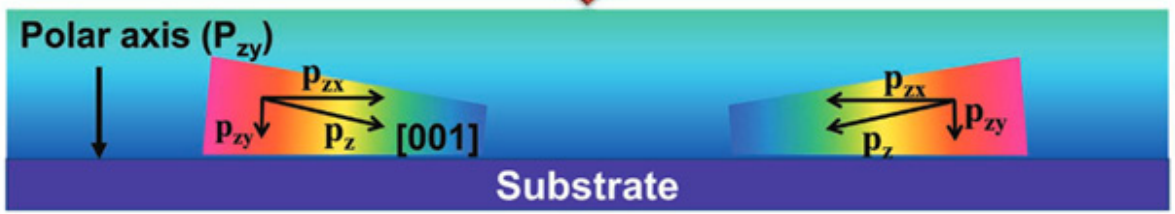

Fig. 13. (a)-(b) $\mathrm{ZnSnO}_{3}$ 삼각 나노벨트가 액체 PDMS내에서 가라앉아 고체화 되는 메커니즘. (c) $\mathrm{ZnSnO}_{3}$ 삼각 나노벨트를 이용한 압전발전 소자의 구동원리22)

단한 합성 방법으로 저렴하고 유연한 대면적 압전 물질합 성을 성공한 이 연구를 기반으로 압전 나노발전기의 상업 적 활용 가능성을 보여주었다.

$\mathrm{ZnO}$ 는 $\mathrm{n}$-타입 반도체 물질이면서 압전 특성을 가지
고 있으며 나노로드, 나노벨트, 나노링 등 다양한 형상으 로 합성이 가능하여 센서, 에너지 하베스터로서 연구한 많은 논문들이 보고되었다. $\mathrm{ZnSnO}_{3}$ 는 $59 \mu \mathrm{Ccm}^{-2}$ 의 압 전 상수를 가지고 있어 이는 $5 \mu \mathrm{Ccm}^{-2}$ 의 압전 상수를 가 (a)

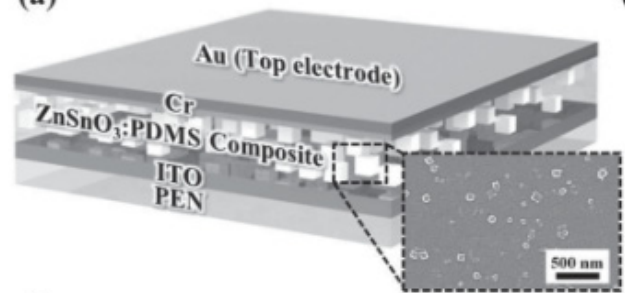

(c)

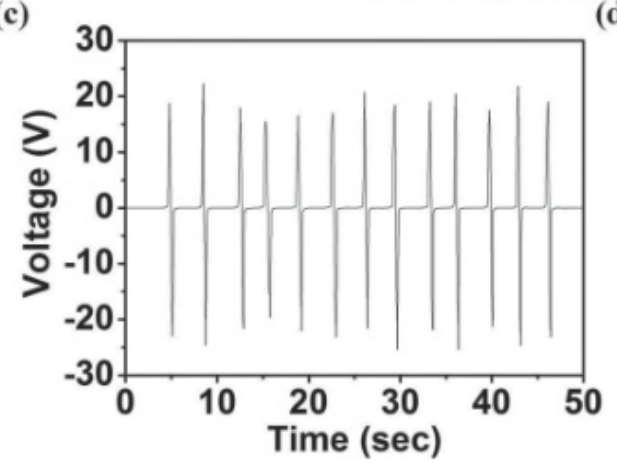

(b)

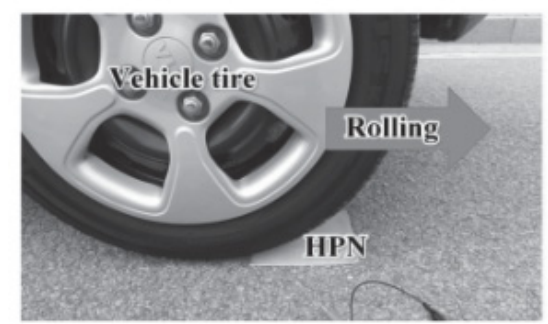

(d)

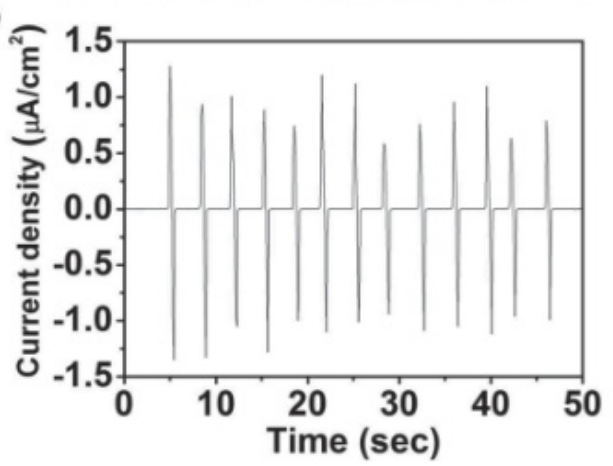

Fig. 14. (a) $\mathrm{ZnSnO} 3: P D M S$ 복합재료 구조도 및 전자현미경 이미지 (b) $\mathrm{ZnSnO}_{3}:: \mathrm{PDMS}$ 로 이루어진 복합소재 압전 소자가 바닥에 부착되어 있 고 그 위로 바퀴가 지나가는 사진. (c), (d) 바퀴의 하중에 의한 출력 전압과 전류밀도 그래프23) 
(a)

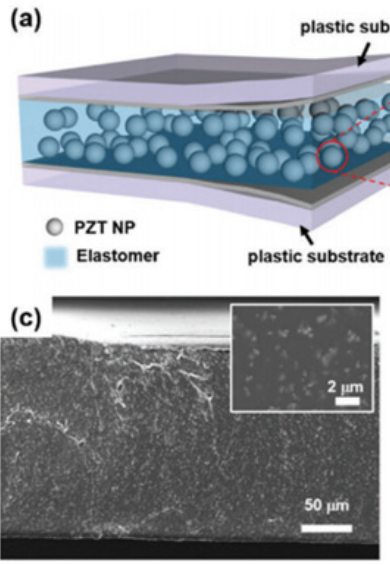

(b)

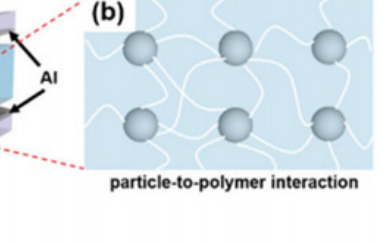

(e)
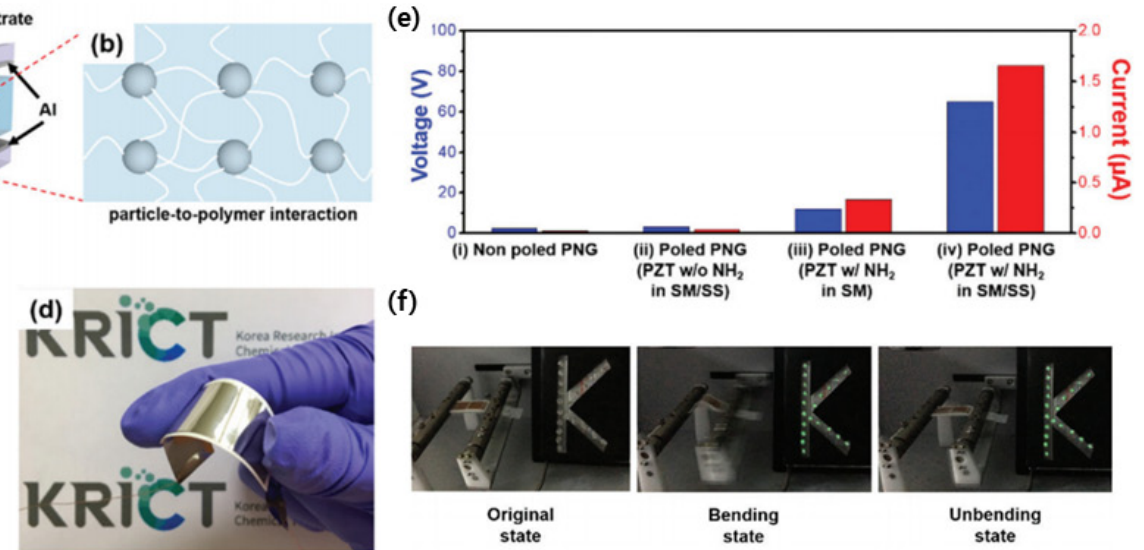

(f)

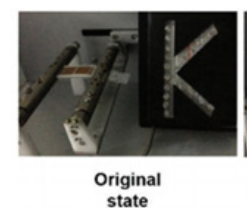

in SM/SS)
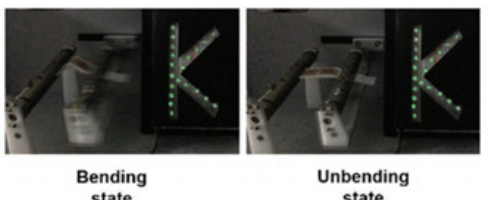

Fig. 15. (a),(b) PZT- $\mathrm{NH}_{2}$ 나노 입자기반 압전 나노발전기의 모식도. (c) PZT- $\mathrm{NH}_{2}$ 나노 입자와 폴리머 복합재료의 전자현미경 단면사진. (d) $\mathrm{PZT}-\mathrm{NH}_{2}$ 나노 입자기반 압전 나노발전기의 실제 사진. (e) (i) 분극처리되지 않은 압전 나노발전기의 출력 전압 및 전류값, (ii) 아민기 가 없는 PZT 나노 입자와 SM, SS 폴리머의 복합재료를 이용한 분극처리된 압전 나노발전기의 출력 전압 및 전류값, (iii) PZT- $\mathrm{NH}_{2}$ 나 노 입자와 $\mathrm{SM}$ 폴리머의 복합재료를 이용한 분극처리된 압전 나노발전기의 출력 전압 및 전류값, (iv) PZT- $\mathrm{NH}_{2}$ 나노 입자와 SM, SS 폴리머의 복합재료를 이용한 분극처리된 압전 나노발전기의 출력 전압 및 전류값. (f) $\mathrm{PZT}-\mathrm{NH}_{2}$ 나노 입자기반 압전 나노발전기를 이 용하여 20개의 녹색 LED를 동시에 켜는 모습. ${ }^{24)}$

지고 있는 $\mathrm{ZnO}$ 보다 12 배 높은 값으로 $\mathrm{ZnSnO}_{3}$ 와폴리머 복합재료를 이용한 압전 에너지 하베스터가 꾸준히 연구 되어 왔다. Georgia Institute of Technology에 Zhong Lin Wang 교수 연구팀에서는 $\mathrm{ZnSnO}_{3}$ 의 삼각형 나노벨 트의 독특한 구조가 PDMS와 복합체를 형성시 액체상태 의 PDMS 내에서 중력에 의해 가라앉으며 unipolar하게 $\mathrm{Z}$ 축 [001] 방향으로 self-assembly되는 것을 확인하여 압전 나노발전기로 응용하는데 성공 하였다(Fig. 13ac.). $\mathrm{ZnSnO}_{3}$ 의 삼각형 나노벨트를 활용한 압전 나노발전 기로 $0.1 \%$ 의 변형에서 $0.13 \mu \mathrm{A}, 5.3 \mathrm{~V}$ 의 출력을 보고하 였다. ${ }^{22)}$

본 그룹에서는 $\mathrm{ZnSnO}_{3}$ 나노입자와 $\mathrm{PDMS}$ 를 모재로한 복합재료를 이용하여 수직 방향의 큰 응력에서 강한 압전 특성을 보임을 확인하였다 ${ }^{23)}$ (Fig. 14a, b.). 기존 굽힘을 이용한 압전 에너지 하베스터의 경우 전기적 분극처리를 이용하여 압전물질의 내부 극성을 한 방향으로 정렬해 주 어야 높은 출력을 보였지만 $\mathrm{ZnSnO}_{3}$ 나노입자와 $\mathrm{PDMS}$ 복합재료의 경우 외부의 강한 응력이 내부 극성의 정렬을 유도하여 압전 특성을 증폭시켜 주고 강한 내구성을 보여 강한 수직 응력에서 $20 \mathrm{~V}, 1 \mu \mathrm{Acm}^{-2}$ 의 높은 압전 나노발 전기 출력을 확인 할 수 있었다(Fig. 14c.). 높은 응력에
서 구동 할 수 있는 압전 나노발전기의 개발로 자동차, 완 충장치에서 버려지는 운동에너지를 이용한 발전체로서 활용 가능성을 보여주었다.

2018년에는 한국화학연구원과 본 그룹과의 협업으로 화학적 보강 복합재료를 이용한 고출력 압전 나노발전기 개발에 성공하였다. ${ }^{24)}$ 이 연구에서는 기존에 폴리머와 나 노입자를 이용한 복합체를 만들 때 나노 입자들이 뭉쳐 폴리머 내에 균일하게 분포하지 못하고 외부의 응력이 잘 전달되지 않으며 재현성이 떨어지는 문제점을 아민기 $\left(-\mathrm{NH}_{2}\right)$ 를 가지고있는 PZT 나노 입자와 styrene-bethylene/butylene-b-styrene triblock copolymer (SEBS, SS)와 SEBS에 무수말레인산이 첨가된 폴리머 (SM)를 모재를 이용하여 해결하였다(Fig. 15a-d.). SM 폴리머의 anhydride group과 PZT 나노입자의 아민기 그룹 사이의 화학적 결합을 통해 안정적으로 나노입자들 의 분산을 유도할 수 있었고 PZT 나노 입자를 연결 시켜 주는 아민기 그룹과 무수말레인산 사이의 강한 화학적 결 합으로 복합재료에 가해지는 응력을 PZT 나노 입자에 잘 전달 해줌으로서 높은 출력을 보일 수 있었다. 또한 전기 적 분극처리를 방해하는 나노입자의 분산을 돕기 위해 넣 는 금속 충진재를 넣지 않아 전기적 분극처리를 이용한 
압전효율을 더욱 높일 수 있었다(Fig. 15e.). 이러한 장점 을 이용한 $\mathrm{PZT}-\mathrm{NH}_{2}$ 나노 입자기반 압전 나노발전기를 이용하여 20 개의 $\mathrm{LED}$ 를 동시에 구동하는데 성공하였다 (Fig. 15f.).

\section{4. 결론}

에너지 하베스팅 기술의 연구들은 크게 소재개발과 구 조개발로 나뉘어 왔다. 마찰 발전의 경우 마찰표면 전하 밀도를 증폭시킴과 동시에 전하를 유지 할 수 있어야 하 고 마찰에 의한 열과 마모를 견디는 소재를 필요로 한다. 압전 발전에 사용되는 물질은 상황에 따라 인장, 압축응 력에 잘 견디며 높은 극성을 필요로 한다. 세라믹 소재만 을 사용하거나 폴리머 소재만을 사용하여 에너지 하베스 팅 소자에서 필요로 하는 높은 출력을 가지며 강하고 내 구성을 가지는 물질의 특성을 모두 만족 시키는 것은 쉽 지 않을 것이다. 따라서 세라믹, 폴리머, 금속, 바이오물 질, 나노물질과 같은 다양한 소재를 이용한 복합소재를 활용하여 물질 상호간의 단점을 보완하고 에너지 하베스 팅을 필요로 하는 환경에 맞는 구조 및 재료를 개발 나가 야한다. 현재 에너지 발전 소자의 부족한 출력과 낮은 내 구성은 에너지 하베스팅 기술의 상용화를 실현하기에 부 족하지만 혁신적인 복합소재의 개발은 에너지 하베스팅 기술이 상용화 단계로 도약할 수 있는 밑거름이 될 것으 로 기대된다.

\section{참고문헌}

1. H. Ryu, H. J. Yoon and S.-W. Kim, "Hybrid Energy Harvesters: Toward Sustainable Energy Harvesting," Adv. Mater. 1802898 (2019).

2. R. Hinchet, W. Seung and S.-W. Kim, "Recent progress on flexible triboelectric nanogenerators for selfpowered electronics," ChemSusChem 8 [14] 23272344 (2015).

3. H.-J. Yoon, H. Ryu and S.-W. Kim, "Sustainable powering triboelectric nanogenerators: Approaches and the path towards efficient use," Nano Energy 51 173-184 (2018).

4. Z. L. Wang, J. Chen and L. Lin, "Progress in triboelectric nanogenerators as a new energy technology and self-powered sensors," Energy Environ. Sci. 8 [8] 2250-2282 (2015).

5. www.figarosensor.com

6. D. Bhatia, W. Kim, S. Lee, S.-W. Kim and D. Choi, "Tandem triboelectric nanogenerators for optimally scavenging mechanical energy with broadband vibration frequencies," Nano Energy 33 515-521 (2017).

7. H. J. Choi, J. H. Lee, J. Jun, T. Y. Kim, S.-W. Kim and $\mathrm{H}$. Lee, "High-performance triboelectric nanogenerators with artificially well-tailored interlocked interfaces," Nano Energy 27 595-601 (2016).

8. F. R. Fan, Z. Q. Tian and Z. L. Wang, "Flexible triboelectric generator," Nano Energy 1 [2] 328-334 (2012).

9. S. S. Kwak, H. Kim, W. Seung, J. Kim, R. Hinchet and S.-W. Kim, "Fully stretchable textile triboelectric nanogenerator with knitted fabric structures," ACS nano 11 [11] 10733-10741 (2017).

10. H. Ryu, J. H. Lee, U. Khan, S. S. Kwak, R. Hinchet and S.-W. Kim, "Sustainable direct current powering a triboelectric nanogenerator via a novel asymmetrical design," Energy Environ. Sci. 11 [8] 2057-2063 (2018).

11. M. Seol, S. Kim, Y. Cho, K. E. Byun, H. Kim, J. Kim and S. Park, "Triboelectric Series of 2D Layered Materials," Adv. Mater. 30 [39] 1801210 (2018).

12. W. D. Callister Jr. and D. G. Rethwisch, "Materials Science and Engineering: An Introduction," Wiley 8 487 (2009).

13. Z. H. Lin, Y. Xie, Y. Yang, S. Wang, G. Zhu and Z. L. Wang, "Enhanced triboelectric nanogenerators and triboelectric nanosensor using chemically modified $\mathrm{TiO}_{2}$ nanomaterials," ACS nano 7 [5] 4554-4560 (2013).

14. W. Seung, M. K. Gupta, K. Y. Lee, K. S. Shin, J. H. Lee, T. Y. Kim and S.-W. Kim, "Nanopatterned textile-based wearable triboelectric nanogenerator," ACS nano 9 [4], 3501-3509 (2015).

15. W. Seung, H. J. Yoon, T. Y. Kim, H. Ryu, J. Kim, J. H. Lee and S. -W. Kim, "Boosting power generating performance of triboelectric nanogenerators via artificial control of ferroelectric polarization and dielectric properties," Adv. Energy Mater. 7 [2] 1600988 (2017).

16. J. Kim, J. H. Lee, H. Ryu, J. H. Lee, U. Khan, H. 
Kim and S. -W. Kim, "High Performance Piezoelectric, Pyroelectric, and Triboelectric Nanogenerators Based on $\mathrm{P}$ (VDF TrFE) with Controlled Crystallinity and Dipole Alignment," Adv. Funct. Mater. 27 [22] 1700702 (2017).

17. S. A. Han, J. Lee, J. Lin, S.-W. Kim and J. H. Kim, "Piezo/triboelectric nanogenerators based on 2-dimensional layered structure materials," Nano Energy 57 680-691 (2019)

18. T. Y. Kim, S. K. Kim and S.-W. Kim "Application of ferroelectric materials for improving output power of energy harvesters," Nano Convergence 5 [30] (2018)

19. K. I. Park, M. Lee, Y. Liu, S. Moon, G. T. Hwang, G. Zhu, J. E. Kim, S. O. Kim, D. K. Kim, Z. L. Wang and K. J. Lee, "Flexible Nanocomposite Generator Made of $\mathrm{BaTiO}_{3}$ Nanoparticles and Graphitic Carbons," Adv. Mater. 24 [22] 2999-3004 (2012).

20. Y. Kim, K. Y. Lee, S. K. Hwang, C. Park, S.-W. Kim and J. Cho, "Layer-by-Layer Controlled Perovskite Nanocomposite Thin Films for Piezoelectric Nanogenerators," Adv. Funct. Mater. 24 [40] 62626269 (2014).
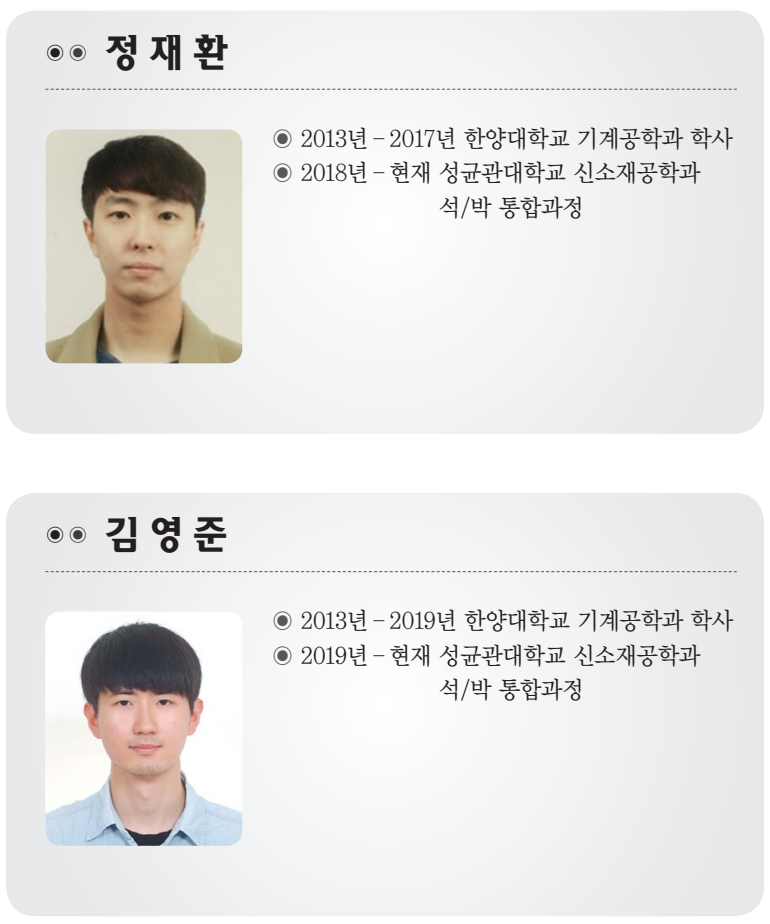

21. G. Zhang, Q. Liao, Z. Zhang, Q. Liang, Y. Zhao, X. Zheng and Y. Zhang, "Novel Piezoelectric Paper Based Flexible Nanogenerators Composed of $\mathrm{BaTiO}_{3}$ Nanoparticles and Bacterial Cellulose," Adv. Sci. 3 [2] 1500257 (2016).

22. J. M. Wu, C. Xu, Y. Zhang, Y. Yang, Y. Zhou and Z. L. Wang, "Flexible and Transparent Nanogenerators Based on a Composite of Lead Free $\mathrm{ZnSnO}_{3}$ Triangular Belts," Adv. Mater. 24 [45] 6094-6099 (2012)

23. K. Y. Lee, D. Kim, J. H. Lee, T. Y. Kim, M. K. Gupta and S.-W. Kim, "Unidirectional High-Power Generation via Stress-Induced Dipole Alignment

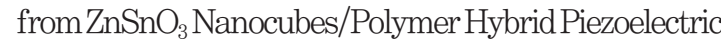
nanogenerator," $A d v$. Funct. Mater. 24 [14] 20382043 (2014)

24. E. J. Lee, T. Y. Kim, S.-W. Kim, S. Jeong, Y. Choi and S. Y. Lee "High-performance piezoelectric nanogenerators based on chemically-reinforced composites," Energy Environ. Sci. 11 [6] 1425-1430 (2018)

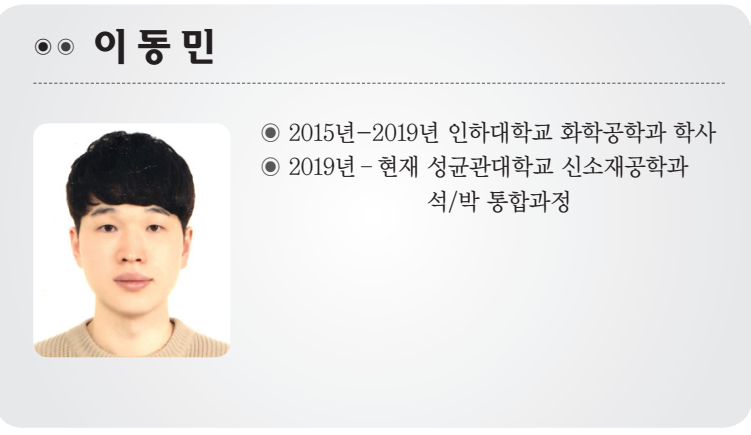

\section{๑ 김상 우}

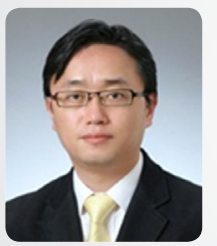

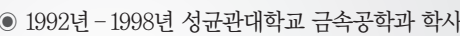
- 1998년 - 2000년 광주과학기술원 신소재공학과 공학석사

- 2001년 - 2004년 Kyoto University, Japan 전자공학 공학박사

○ 2004년 - 2005년 Nanoscience Centre, University of Cambridge, UK 박사 후 연구원

- 2005년 - 2008년 금오공과대학교시소ㅅㅗㅐ시스템공학부 조교수 ○ 2009년 - 현재 성균관대학교 신소재공학부 정교수 